\title{
CASE STUDY
}

\section{Special Moments in Ukrainian and Foreign Students Perception of a Lecturer's Personality}

\author{
Authors' Contribution: \\ A - Study design; \\ B - Data collection; \\ C - Statistical analysis; \\ D - Data interpretation; \\ E - Manuscript preparation; \\ F - Literature search; \\ G - Funds collection
}

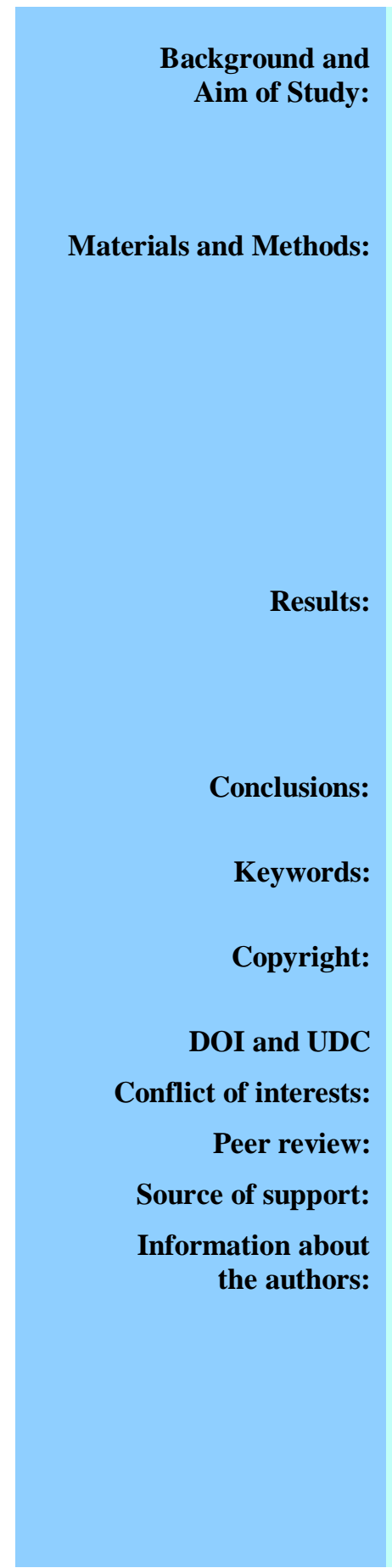

\author{
Bielikova O. V. ${ }^{1 \mathrm{ABDEFG}}$, Dytiuk S. O. ${ }^{1 \mathrm{ABDEFG},}$ \\ Krech T. V. ${ }^{1}$ ABDEFG
}

${ }^{1}$ Kharkiv National University of Civil Engineering and Architecture, Ukraine

Received: 24.01.2019; Accepted: 25.02.2019; Published: 30.03.2019

\section{Abstract}

In process of introduction of new requirements and standards of teaching, significant transformations of lecturer and student's interaction take place. A system of role expectation as to lecturer's main qualities changes.

The aim of the study: to research and justify of theoretical basements of diagnostics of results of forming professional competencies of pedagogues in universities.

For analyzing special features of language training lecturer's perception that are important for students of our university we conducted a survey: "A lecturer in foreign students' eyes". Students of faculty of construction and faculty of architecture of Kharkiv National University of Civil Engineering and Architecture took part in it. This survey been held in several stages. On stage one foreign students of elder grades had to finish the sentence: "Modern university lecturer should be ..." by using their own thoughts. After processing the results of our survey, we made a list of lecturer's features that are important for students. Students of younger grades had to rank the features from the list we got. Our research has been held for 10 years. We have been using methods of covert surveillance and partial distributive analysis of researched material.

For Ukrainian and foreign students image of their lecturer consists of many subjective factors of perception and includes several groups of qualities: personal qualities, that characterize lecturer as a person; professional qualities, that characterize lecturer's professional level; and social qualities, that characterize lecturer's communicative skills and his ability to "stay in touch" with students.

Effectiveness and optimization of Ukrainian and foreign students' teaching process depends both on lecturer's pedagogical masterpiece and on his character.

lecturer's professional competence, Ukrainian and foreign students, universities of technical profile, competence approach, professional graphic monitoring.

(C) 2019 Bielikova O. V., Dytiuk S. O., Krech T.V. Published by Archives of International Journal of Education and Science

DOI 10.26697/ijes.2019.1.02; UDC 37.015.3:37.032

The authors declare that there is no conflict of interests

Double-blind review

Departmental sources

Bielikova Olena Vitaliivna - $\quad$ http://orcid.org/0000-0001-8580-112X; belikova.lenochka@gmail.com; Senior Lecturer, Kharkiv National University of Civil Engineering and Architecture; Kharkiv, Ukraine.

Dytiuk Svitlana Oleksiivna (Corresponding Author) - http://orcid.org/0000-0001-8580112X; svetlanadytiuk@gmail.com; Senior Lecturer, Kharkiv National University of Civil Engineering and Architecture; Kharkiv, Ukraine.

Krech Tetiana Vasylivna - http://orcid.org/0000-0003-0865-1716; tatianakrech@gmail.com; Doctor of Philosophy in Philology, Professor, Head of the Department of Ukrainian Language and Language Training of Foreign Citizens, Kharkiv National University of Civil Engineering and Architecture; Kharkiv, Ukraine. 


\section{Introduction}

In conditions of social and economic changes in Ukraine, improving quality of a professional higher education system, in process of introduction of new requirements and standards of teaching, significant transformations of lecturer and student's interaction take place. Changes, first of all, concern to lecturer's perception, a system of role expectation as to lecturer's main qualities changes. That's why one of the most important questions in nowadays pedagogical discussions is a question about lecturer's identity, his professional activity, about demands that are being made to him.

Taking into attention special moments in foreign and Ukrainian students, it can be said that lecturer who trains students:

- must have skills not only in language training, but also be familiar with culture of the countries that his students came from;

- must be native to language and culture of the country; - must also know everything about culture of his students' countries and highlight differences between cultures to his students;

- must master the culture of the language (his speech should be clean, diverse, different in words), stick to language etiquette.

Analysis of the latest researches and publications says that this problem is very promising. Actual problem of pedagogue's professional skills been researched by the following scientists: Kharlamov; Klimov; Melnyk (2017); Melnyk and Pypenko (2018); Podlasiy (2015); Slastenin, Isayev, and Shiyanov (2015); Zimnyaya (2010); Zyazun and others. Main ideas that unite different points of view of mentioned researches are the following - university lecturer is a person who, because of his professional activity, should have such professional qualities as: be a scientist, a practicing pedagogue, a mentor, a psychologist, master the technology of education process and procure the unity of educational, scientifical and innovational activities (Podlasiy, 2015; Slastenin, Isayev, \& Shiyanov, 2015; Zimnyaya, 2010). Psychologist Krutetskiy suggests the following structure of modern lecturer's personality: world view, positive attitude to pedagogical activity, pedagogical abilities, professional pedagogical knowledge, skills.

Aggregate of professional demands to lecturer is specified as his professional willingness for his pedagogical activity. Inside it will be right to highlight, at one side, psychological and physical readiness, and at the other side - scientifical and practical competence as a basement for professionalism. System of professional demands to pedagogue consists of his professional competence. Till nowadays there is a lot of experience in building lecturer's professional competence, and it allows to split professional demands on three main groups, that are connected and complement each other: general citizen qualities; qualities that specify lecturer's profession; special experiences and skills. Lecturer's rhetorical masterpiece can't be something constant, it should be approved year after year. It is necessary to highlight main factors that have influence on student's language sense, raising esthetical preferences, forming general and professional culture. Sense of word, term accuracy - is a must in lecturer's rhetorical masterpiece.

Among the researches devoted to language culture and rhetorical masterpiece training, works by Bakhtin (1986); Vasil'ev (2015); Volkogonova and Chaplygin (2005) should be mentioned.

Facts of language and culture not always can be demarcated, contrasted: changes in culture are reflected in language, and language evolution influes on cultural processes.

All the attempts to in vitro move language facts behind the line of cultural processes inside society lead to decreasing role of language as a main factor of nation's cultural value.

Language was, and it still is main instrument of sociocode - primary reality of national culture. Such interconnections of sociocode can be seen in, e. g., changes of connotative meanings in words like "maidan", "dignity revolution", etc.

The most important criteria, from a cultural point of view, in level of lecturer's rhetorical masterpiece is his vocabulary, that shows and fastens in students' minds facts of surrounding reality, defines speaking behavior in different situations.

It is well known that lexical content of any language fastens and passes from generation to generation specifics of ethno cultural norms, supporting in this way continuity and sustainability of ethnic mentality. Analysis of lexical culture, formed in student's mind, lets check the condition of his intellectual development and even predict the upcoming transformations.

In general, there are many works devoted to forming language personality, it is enough to remember fundamental work by Karaulov (1987).

Since every native speaker is at the same time culture carrier, "language signs acquire ability to perform a function of culture signs, and thereby serve as a tool for the presentation of the basic settings of culture" (Vereshhagin \& Kostomarov, 1976).

It is precisely determined by language, according to famous Ukrainian writer Gonchar thoughts, not only nation's mind, its esthetic taste, but also its moral. The world around us every day, every second influes on forming worldview values, general culture, one of the manifestations of which is language culture and situationally justified language behavior.

Unfortunately, with appearance of personal computers and Internet work with any sources became much easier, as it is possible to download printable texts, and World Wide Web is full of promos that offer essays, term papers and dissertations to buy.

On the one hand, you can't resist comfort and technical progress that became a sign of $21^{\text {st }}$ century, but on the other hand, authenticity of knowledge is being replaced by commercial phantoms.

A whole generation is growing, infected by the subculture of Internet communication, characterized by the lack of strict rules and regulations of the text formalization. Literacy drops catastrophically, associative thinking, the wealth of the imaginative 
system is increasingly giving way to language cliches and soulless schemes. Every decade vocabulary of a middle school graduate becomes poorer by $20-30 \%$.

The illiteracy virus even penetrates into professional sphere of journalists, broadcasters, radio and television. This misfortune in the era of globalization has acquired global proportions: today $70 \%$ of young Japanese don't know how to write hieroglyphs.

The aim of the study. To research and justify of theoretical basements of diagnostics of results of forming professional competencies of pedagogues in universities.

\section{Materials and Methods}

For analyzing special features of language training lecturer's perception that are important for students of our university we conducted a survey: "A lecturer in foreign students' eyes". Students of faculty of construction and faculty of architecture of Kharkiv National University of Civil Engineering and Architecture took part in it. We set some definite tasks for studying personality of a modern lecturer, namely to determine:

1. Foreign students' general image about requirements to university pedagogue;

2. The most important for foreign students' characteristics in lecturer's professiogram;

3. Dynamics of university lecturer's image in the eyes of foreign students of different years of study.

This survey been held in several stages. On stage one foreign students of $3^{\text {rd }}, 4^{\text {th }}$ and $5^{\text {th }}$ year of study had to finish the sentence: "Modern university lecturer should be ..." by using their own thoughts. After processing the results of our survey, we made a list of lecturer's features that are important for students. Students of $1^{\text {st }}$ and $2^{\text {nd }}$ years of study had to rank the features from the list we got. Analysis of survey results showed the existence of two main groups: professional skills and personal qualities of a pedagogue.

Our research been held for 10 years, students from different faculties and specialties took part in it, but placement of priorities matched at about 85-90\% level. In our research, we have been using methods of covert surveillance and partial distributive analysis of researched material.

\section{Results}

After analyzing psychological and pedagogical literature about the definitions mentioned above, we came up to a decision that the following competencies of a lecturer of foreign citizens' language training can be highlighted (Andreeva, 2014; Kichuk, 2007; Melnyk (2017); Melnyk and Pypenko (2018); Ortynskyi, 2017; Ovcharuk, 2004; Panina \& Makarenko, 2017; Slastenin, Isayev, \& Shiyanov, 2015; Zimnyaya, 2010):

1. General humanitarian competence. Problems of intercultural communication may be solved only under conditions of sufficient level of general humanitarian competence.

2. Linguistic competence. Knowledge of all key moments of the language he teaches is a main competence for language pedagogue.
3. Psychological competence. Teaching language will be successful if lecturer will take into attention personal qualities of his students, psychology of pedagogical activity and communication.

4. Pedagogical competence. Knowing base pedagogical conceptions, principles, categories and definitions, general knowledge about teaching methods lets lecturer optimize teaching process.

5. Methodical competence. Basement of this competence is in knowing theories, conceptions, methodical systems in teaching foreign students; in mastering skills and ways that allow teaching foreign students language.

6. Professional communicative competence. Ability to set optimal pedagogical connection with all participants of language teaching process, as a condition of lecturer's professional competence.

Types of competencies of a lecturer of foreign citizens' language training are illustrated in Figure 1.

According to results of our survey, foreign students consider that lecturer should have the following qualities and skills: professionalism ("easily explain", "explain difficult moments", "answer the questions"), rhetorical mastery ("teach in an interesting way", "speak in easy manner", "speak legibly"), communicability ("be communicable", "communicate respectfully", "be open to student", "be a friend for student"), wide area of thought ("open minded", "smart", "knows much"), mastery in subject ("be a master in subject", "deep knowledge"), kindness ("kind", "in good relations with students", "help a student"), self-control ("do not cry at students", “ do not tease at students", "be calm"), internationalism ("don't be racist", "keep in mind that all students are equal: Ukrainian and foreign"), tolerance ("show respect to foreign culture", "show respect to foreign religion"), appearance ("good-looking", “neat"), empathy ("help the students"), strict, objective, honorable to students. The most important skills appeared to be: "don't be a racist" - $60 \%$, "easily explain" - 55\%, "be a master in subject" - 40\%, "smart" - 38\%, "be calm" - 33\%, "in good relations with students" - 30\%, "be communicable" - 30\%, "honorable to students" $-27 \%$.

During comparing characteristics given by students of younger and elder grades, we found out the following regularities.

Students of younger grades value lecturer's attitude more than his professional skills, master level, knowledge base: for younger grade student it is more important how lecturer communicates them, how kind he is, his tact. In evaluation of modern pedagogue image they value his personal qualities more. At $1^{\text {st }}$ place students of first and second grades put such quality as "being honorable to students", on $2^{\text {nd }}$ place "internationalism", on $3^{\text {rd }}$ place - "kindness" and "communicability", on $4^{\text {th }}-$ "easily explain", on $5^{\text {th }}-$ "help a student".

Students of third, fourth and fifth grades value personal qualities of a lecturer and his professional skills at same degree. They highlight the qualities that relate to professional and personal qualities of a lecturer: "be a master in subject" and "easily explain" ( $1^{\text {st }}$ place); 
"honorable to students" and "kindness" ( $2^{\text {nd }}$ place); "self-control" ( $3^{\text {rd }}$ place); "objective" and "communicability" (4 $4^{\text {th }}$ place $) ;$ “appearance" $\left(5^{\text {th }}\right.$ place); internationalism ( $6^{\text {th }}$ place).

After analyzing the data above, the following conclusions can be made:

- In their lecturer foreign students should see a patriot of Ukraine. At the same time it is totally unacceptable for him to be a nationalist, to dishonor other countries or nations;

- An image of a lecturer consists of many factors of perception by students and contains several groups of qualities: personal qualities, that characterize lecturer as a personality; professional skills, that characterize his professional activity; social skills, that characterize his communicative skills, interaction with students;

- During teaching process lecturer's image in the eyes of the students' changes;

- Effectiveness and optimization of teaching process in language training depends both on pedagogical mastership - knowledge and skills in linguistics, pedagogics and psychology, and on personal qualities of lecturer's person.

The most frequent lecturer's characteristics, mentioned by foreign and Ukrainian students, are shown in Table 1.

Upon comparative characteristics of leveling lecturer's qualities by students of younger grades, we found out the following consistent patterns (see Table 2).

Upon ranging lecturer's qualities by students of higher grades the results were the following (see Table 3 ).

\section{Discussion}

Comparative analysis of lecturer's most frequent characteristics, mentioned by Ukrainian and foreign students, showed that Ukrainian students highlight professional and personal qualities of their lecturer at the same degree, when foreign students highlight lecturer's personal qualities, accenting their attention on internationalism and tolerance. Good lecturer, according to their opinion, should understand and accept values of another cultures and worldviews, be indulgent to foreign opinions, feelings, behaviors, specialties of nations and religions.

Ukrainian and foreign students of younger grades pay not as much attention to lecturer's professional skills and scientific level, as to lecturer's relation to the students: for younger grade student it is important how he's being treated, how kind their lecturer is.

Tkachova (2015, p. 77) highlights personal qualities of a pedagogue as main, as ones that affect students' education level. "Pedagogue's influence consists of his professional qualities, as a person who is master in his subject, and influence of his person, spirituality, emotionality. At the same time, personal skills are much more important than professional skills for students. When students appreciate their lecturer, it guarantees their love to him and his subject".

For Ukrainian students of $3^{\text {rd }}, 4^{\text {th }}$ and $5^{\text {th }}$ grades professional and personal qualities of a lecturer is equally important. By putting on first place "Knowing his subject", "Rhetorical masterpiece", "Ability to combine theory and practical experience", students highlight also personal qualities, that characterize lecturer's intellect and his objectiveness.

Foreign students of higher grades accent their attention on lecturer's professional qualities, but also pay much attention to personal characteristics. Among lecturer's personal qualities the most important for foreign students are: "Respectful and communicable", "Selfcontrol", "Objectivity in student knowledge assessment”, “Appearance”, "Internationalism”.

Rudneva, Astakhova, and Lapshova (2008, p. 56) adds cognitive component and practical skills to modern lecturer's professional competence.

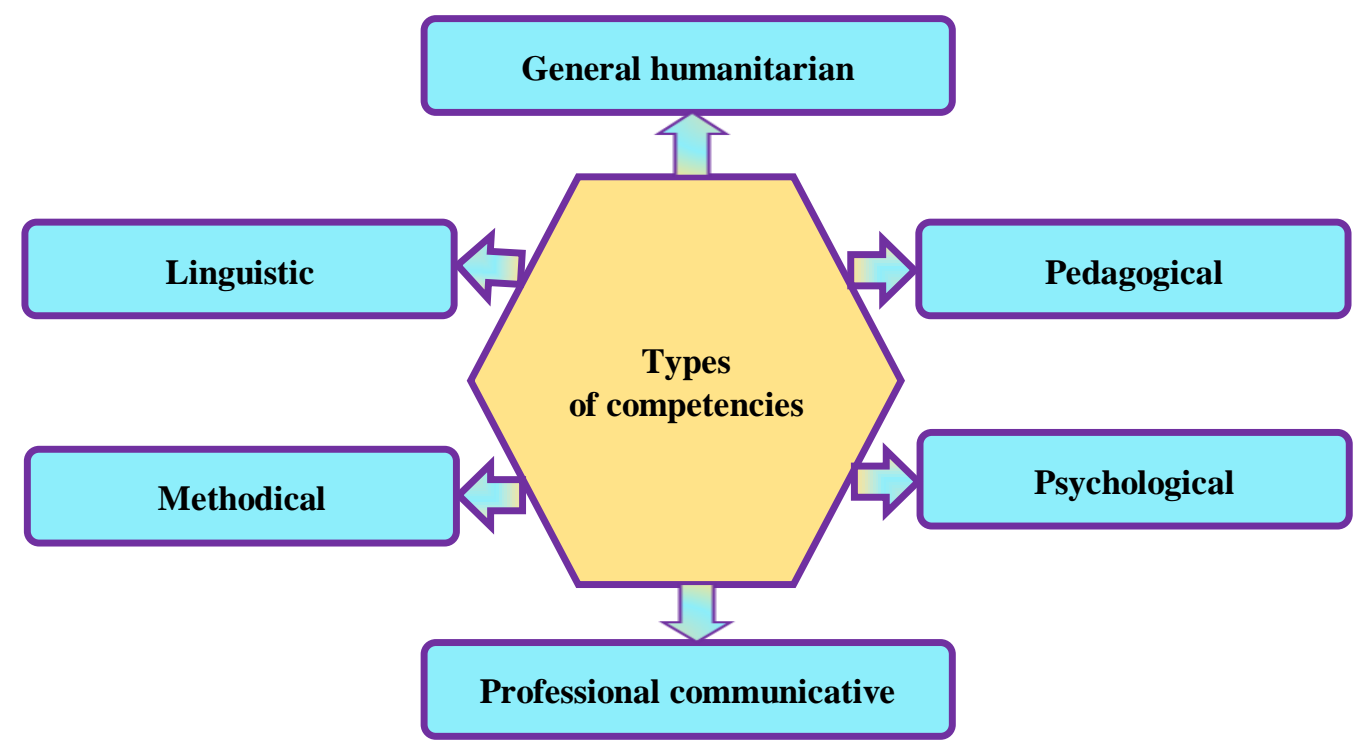

Figure 1. Types of competencies of a lecturer of foreign citizens' language training. 
Table 1. Lecturer's characteristics, mentioned by foreign and Ukrainian students.

\begin{tabular}{|l|l|}
\hline \multicolumn{1}{|c|}{ Characteristics mentioned by Ukrainian students } & \multicolumn{1}{c|}{$\begin{array}{c}\text { Characteristics mentioned by foreign } \\
\text { students }\end{array}$} \\
\hline Knowing his subject $-65 \%$ & $\begin{array}{l}\text { Don't be racist, show respect to students' } \\
\text { culture, religion }-60 \%\end{array}$ \\
\hline Understanding $-50 \%$ & Can explain clearly $-55 \%$ \\
\hline Communicable $-45 \%$ & Knowing his subject $-40 \%$ \\
\hline Can explain clearly $-45 \%$ & Erudite $-38 \%$ \\
\hline Can interest the student $-40 \%$ & Being patient and calm $-33 \%$ \\
\hline Can keep student's attention $-38 \%$ & Be in good relations with him students $-30 \%$ \\
\hline Erudite $-30 \%$ & Communicable $-30 \%$ \\
\hline Kind $-20 \%$ & Kind $-20 \%$ \\
\hline With a sense of humor $-15 \%$ & Show respect to student $-27 \%$ \\
\hline
\end{tabular}

Table 2. Ranging lecturer's qualities by students of younger grades.

\begin{tabular}{|c|c|}
\hline $\begin{array}{c}\text { Characteristics mentioned by Ukrainian } \\
\text { students }\end{array}$ & Characteristics mentioned by foreign students \\
\hline Kindness & Respectful attitude to the student \\
\hline Responsiveness & Internationalism \\
\hline Mutual understanding & Kindness and communicability \\
\hline Empathy & Can explain clearly \\
\hline Sympathy & Understanding the student \\
\hline Justice & Help the student \\
\hline
\end{tabular}

Table 3. Ranging lecturer's qualities by students of higher grades.

\begin{tabular}{|l|l|}
\hline \multicolumn{1}{|c|}{$\begin{array}{c}\text { Characteristics mentioned by Ukrainian } \\
\text { students }\end{array}$} & Characteristics mentioned by foreign students \\
\hline Knowing his subject & Knowing his subject and can explain it clearly \\
\hline Rhetorical masterpiece & Respectful and communicable \\
\hline Ability to combine theory and practical experience & Self-control \\
\hline Wide area of thought & Objectivity in student knowledge assessment \\
\hline Self-development tendency & Appearance \\
\hline Objectivity & Internationalism \\
\hline
\end{tabular}


Summary of the experiment shows us that lecturer's language culture, his rhetorical masterpiece and communicability skills are always in Top-5 of qualities that students want to see in their lecturer.

In our opinion, exactly these qualities worth much attention. But these research do not set analyzing two components of common dialectic process - improving lecturer's rhetorical masterpiece and raising student's language culture - as one of its goals, though these two processes are connected, and that grants their success. In our research we set as goal to find out how different components of lecturer's rhetorical masterpiece affects on lection course in general. One of rhetorical masterpiece parameters is the pace of lecturing.

Our experiment showed that upon changing pace of lecturing, making it different from generally accepted standards (100 to 120 word per minute) that is suitable for perception, occurs loss of students' attention, perception time limit decreases from 20 minutes, students make mistakes in their précis. Both of low pace and high pace of lecturing cause mentioned effects.

Percent of mistakes is in proportion to pace of lecturing change - changing pace on $20-30 \%$ leads to same amount of mistakes in students' précis.

We also tried to analyze the influence of modern social cultural processes on forming language and professional profile of a student.

According to all written above, we came up to a conclusion that for Ukrainian and foreign students image of their lecturer consists of many subjective factors of perception and includes several groups of qualities: personal qualities, that characterize lecturer as a person; professional qualities, that characterize lecturer's professional level; and social qualities, that characterize lecturer's communicative skills and his ability to "stay in touch" with students. Effectiveness and optimization of Ukrainian and foreign students' teaching process depends both on lecturer's pedagogical masterpiece and on his character.

Interaction becomes more efficient when lecturer and his students are in trustful relations, and conditions for opening personal potential of students created.

At any case of interaction of lecturer with each separate group of his students, his personality has strong effect: his professionalism, scientific potential, individual qualities, culture and worldview; that promotes multilateral communication, effective relations between participants of study process, interactive dialog, realization of co-working strategies between them.

Lecturer's intellectual potential, his general and professional culture, rhetorical masterpiece and his interest in student's success should become an effective tool of formation of language and professional personality, like an antidote to mass subculture influence.

Lecturer's speech should become an example of oratory masterpiece for students, and the results of our experiment confirm that, same as role of rhetorical masterpiece defined by students.
In the future we are going to develop a scale of components of lecturer's rhetorical masterpiece, and influence of lecturer's masterpiece level on success of his lection course.

\section{Conclusions}

Thereby, increased attention to questions of diagnosing language training lecturers' professional levels demands not only scientific look and analysis, but also a new look on systems of pedagogical diagnostics. System diagnostics based on competence approach must become a key and pass-through component in monitoring professional competence of a lecturer in foreign citizens' language training in technical universities.

An object for continuing studies is a study of an essence and structure of components for diagnosing professional competencies; definition of variable and invariable components of foreign students language training pedagogue's professional competencies; justification of model and methods of system diagnostics of professional competencies.

\section{References}

Andreeva, G. M. (2014). Socialnaja psihologija [Social psychology] (5th ed.). Moscow: Aspekt Press. [in Russian]

Bakhtin, M. M. (1986). Problema teksta v lingvistike, filologii $i$ drugikh gumanitarnykh naukakh [Problem of text in linguistics, philology and other human sciences]. In M. M. Bakhtin (Ed.), Jestetika slovesnogo tvorchestva - Aesthetics of verbal creativity (pp. 297-325). Moscow. [in Russian]

Jakobson, R. (1965). Itogi Devjatogo kongressa lingvistov [The results of the Ninth congress of linguists]. Novoe $v$ lingvistike - New in linguistics, 4, 361. [in Russian]

Karaulov, Yu. N. (1987). Russkij yazyk i yazykovaja lichnost [Russian language and language personality]. Moscow: Science. [in Russian]

Kichuk, N. V. (Ed.) (2007). Kompetentnost samorazvitija specialista: pedagogicheskie osnovy formirovanija $v$ vysshej shkole [Competence of the specialist's selfdevelopment: the pedagogical foundations of the formation in higher education]. Izmail: IGGU. [in Russian]

Kompetentnostnyj podhod v sovremennom obrazovanii: mirovoj opyt i ukrainskie perspektivy [Competence approach in modern education: international experience and Ukrainian perspectives]. (2004). In O. V. Ovcharuk (Ed.), Biblioteka po obrazovatel'noj politike - Library for educational policy. Moscow: "K.I.S". [in Russian]

Melnyk, Yu. (2017). Study of trends of students' demand for the formation of competences by higher educational institutions. Science and Education, 5, 128-134. doi:10.24195/24144665-2017-5-22 
Melnyk, Yu. B., \& Pypenko, I. S. (2018). Training of future specialists in higher education institutions. International Journal of Science Annals, 1(1-2), 4-11. doi:10.26697/ijsa.2018.12.01

Metodyka navchannia ukrainskoi movy (2016, February 24). [Methodology of teaching the Ukrainian language]. StudFiles. Retrieved from https://studfiles.net/preview/5537864/page:13/ [in Ukrainian]

Muras, A. (2007). Vykladannia ukrainskoi movy yak inozemnoi $\mathrm{v}$ Universyteti imeni Adama Mitskevycha v Poznani [Teaching Ukrainian as a Foreign Language at the Adam Mickiewicz University in Poznan]. Teoriia $i$ praktyka vykladannia ukrainskoi movy yak inozemnoi Theory and Practice of Teaching Ukrainian as a Foreign Language, 2, 258-261. [in Ukrainian]

Novikov, L. A. (1970). Russkyi yazyk kak ynostrannyi y osnovnye voprosy eho opysanyia [Russian as a foreign language and the main questions of its description]. Russkyi yazyk za rubezhom Russian language abroad, 4(16). [in Russian]

Ortynskyi, V. L. (2017). Pedahohika vyshchoi shkoly [High school pedagogy]. Kyiv: Center for Literature Studies. [in Ukrainian]

Panina, S. V., \& Makarenko, T. A. (2017). Samoopredeleniye $i$ professionalnaya oriyentatsiya uchashchikhsya [Selfdetermination and professional orientation of students] (3rd ed.). Moscow: Yurayt. [in Russian]

Podlasiy, I. P. (2015). Pedagogika [The pedagogy]. Moscow: VLADOS. [in Russian]

Rudneva, T. I., Astakhova, S. V., \& Lapshova, E. S. (2008). Professional'naya podhotovka spetsialistov humanitarnoho profilia [Professional training of specialists of humanitarian profile] [Monograph]. Samara: Samara University. [in Russian]

Salistra, I. D. (1966). Ocherki metodov obucheniya inostrannym yazykam [Essays on methods of teaching foreign languages]. Moscow: Vysshaja shkola. [in Russian]

Shubin, Je. P. (1972). Pozitivnye i negativnye aspekty vliyaniya pervogo yazyka na ovladenie vtorym na razlichnyh urovnyah yazykovoj sistemy [Positive and negative aspects of the influence of the speaker language on mastering the second on different levels of the language system]. Inostrannye yazyki $v$ shkole, 5, 27-32. [in Russian]

Slastenin, V. A., Isayev, I. F., \& Shiyanov, Ye. N. (2015). Pedagogika: [The pedagogy]. Moscow: School Press. [in Russian]

Tkachova, T. M. (2015). Rol' lichnosti v obespechenii kachestva prfessional'noy podgotovki vypusknikov vuza [The role of the individual in ensuring the quality of vocational training of graduates of the university]. Moscow: MADI. [in Russian]
Vasil'ev, A. D. (2015). Slovo v rossijskom teleefire [The word on Russian television]. Moscow: Nauka. [in Russian]

Vereshhagin, E. M., \& Kostomarov, V. G. (1976). Jazyk $i$ kul'tura: Lingvostranovedenie. [Language and culture: Linguistic studies]. Moscow: Nauka. [in Russian]

Volkogonova, O. D., \& Chaplygin, A. K. (2005). Orientirujas' na Bolonskij protsess: opyt transformatsii vysshego obrazovaniya $v$ Rossii $i$ Ukraine [Focusing on the Bologna process: the experience of the transformation of higher education in Russia and Ukraine]. Suchasni tekhnolohii pidhotovky fakhivtsiv $v$ umovakh podalshoho rozvytku vyshchoi osvity Ukrainy Modern technologies of training specialists in conditions of further development of higher education in Ukraine (pp. 192-194). Kharkiv: HNADU. [in Russian]

Zimnyaya, I. A. (2010). Pedagogicheskaya psikhologiya [Pedagogical psychology] (3rd ed.). Moscow: MPSI; Voronezh: NPO "MODJeK". [in Russian]

\section{Література}

Андреева Г. М. Социальная психология: учеб. 5-е изд., испр. и доп. Москва: Аспект Пресс, 2014. 362 c.

Бахтин М. М. Проблема текста в лингвистике, филологии и других гуманитарных наук. Эстетика словесного творчества/под ред. М. М. Бахтина. Москва, 1986. С. 297-325.

Якобсон Р. Итоги Девятого конгресса лингвистов. Новое в лингвистике. 1965. Вып. 4. С. 361.

Караулов Ю. Н. Русский язык и языковая личность. Москва: Наука, 1987. 379 с.

Компетентность саморазвития специалиста: педагогические основы формирования в высшей школе/под ред. Н. В. Кичук. Измаил: ИГГУ, 2007. $236 \mathrm{c.}$

Компетентностный подход в современном образовании: мировой опыт и украинские перспективы. Библиотека по образовательной политике/под общ. ред. А. В. Овчарук. Киев: К.И.С., 2004. 112 с.

Melnyk Yu. Study of trends of students' demand for the formation of competences by higher educational institutions. Science and Education. 2017. № 5. P. 128-134. doi:10.24195/24144665-2017-5-22

Melnyk Yu. B., Pypenko I. S. Training of future specialists in higher education institutions. International Journal of Science Annals. 2018. Vol. 1. № 1-2. P. 4-11. doi:10.26697/ijsa.2018.1-2.01

Методика навчання української мови. StudFiles: веб-сайт. URL: https://studfiles.net/preview/ 5537864/page:13/(дата звернення 14.12.2018).

Мурас А. Викладання української мови як іноземної в Університеті імені Адама Міцкевича в Познані. Теорія $i$ практика викладання украӥнської мови як іноземної. 2007. Вип. 2. С. 258-261. 
Новиков Л. А. Русский язык как иностранный и основные вопросы его описания. Русский язык за рубежсм. 1970. Вып. 4 (16).

Ортинський В. Л. Педагогіка вищої школи: навч. посіб. Київ: Центр учбової літератури, 2017. $470 \mathrm{c}$.

Панина С. В., Макаренко Т. А. Самоопределение и профессиональная ориентация учащихся: учебн. 3-е изд.. Москва: Юрайт, 2017. 312 с.

Подласий И. П. Педагогика. Москва: ВЛАДОС, 2015. $398 \mathrm{c}$.

Руднева Т. И., Астахова С. В., Л Лапшова Е. С. Профессиональная подготовка специалистов гуманитарного профиля: монография. Самара: Изд-во "Самарский университет", 2008. 249 c.

Салистра И. Д. Очерки методов обучения иностранным языкам. Москва: Высшая школа, 1966. $251 \mathrm{c.}$

Шубин Э. П. Позитивные и негативные аспекты влияния первого языка на овладение вторым на различных уровнях языковой системы. Иностранные языки в школе. 1972. № 5. C. 27-32.

Сластенин В. А., Исаев И. Ф., Шиянов Е. Н. Педагогика: учеб. пособ. Москва: ШколаПресс, 2015. 512 c.

Ткачова Т. М. Роль личности в обеспечении качества прфессиональной подготовки выпускников вуза: учебн. пособ. Москва: МАДИ, 2015. $76 \mathrm{c.}$

Васильев А. Д. Слово в российском телеэфире. Москва: Наука, 2015.

Верещагин Е. М., Костомаров В. Г. Язык и культура: Лингвострановедение. Москва: Наука, 1976. 356 с.

Волкогонова О. Д., Ч Чаплыгин А. К. Ориентируясь на Болонский процесс: опыт трансформации высшего образования в России и Украине. Сучасні технології підготовки фахівців в умовах подальшого розвитку вишої освіти України: матеріали міжн. конф., 27-28 жовт. 2005 р. Харків: ХНАДУ, 2005. С. 192-193.

Зимняя И. А. Педагогическая психология: учебн. 3е изд., пересм. Москва: МПСИ; Воронеж: НПО “МОДЭК”, 2010. 448 с.

Особливості сприйняття особистості викладача українськими та іноземними студентами Бєлікова О. В. ${ }^{1}$, Дитюк С. О. ${ }^{1}$, Креч Т. В. ${ }^{1}$

${ }^{1}$ Харківський національний університет будівництва та архітектури, Україна

\section{Анотація}

Bcmyn: У прочесі впровадження нових вимог $i$ стандартів навчання відбуваються значні трансформачії у взаємодії викладача та студента. Змінюеться система рольових очікувань щуодо провідних якостей педагога. Мета дослідження: Дослідити й обтрунтувати теоретичні основи діагностики результатів формування професійних компетениій педагогів із мовної підготовки іноземних громадян у закладах вищої освіти. Матеріали і Методи: Для вивчення особливостей сприйняття особистості викладача, які $\epsilon$ значущими для студентів нашого університету, нами було проведено опитування: «Викладач очима студентів». У ньому взяли участь украӥнські й іноземні студенти будівельного й архітектурного факультетів Харківського національного університету будівниитва та архітектури. Це дослідження проводилося в кілька етапів. На першому етапі експерименту іноземним студентам старших курсів пропонувалося закінчити речення: “Сучасний викладач університету повинен бути ...”, використовуючи власні формулювання. Після обробки результатів иих опитувань був складений список значущих для студентів характеристик особистості викладача. Студенти молодших курсів мали ранжувати характеристики особистості зі списку, який ми отримали. Наше дослідження проводилося 10 років. Ми використовували методи прихованого спостереження та часткового дистрибутивного аналізу досліджуваного матеріалу. Результати: Для українських та іноземних учнів образ викладача вищої школи складається з багатьох суб'єктивних факторів сприйняття студентів $і$ включає кілька груп якостей: індивідуально-особистісні, щцо характеризують викладача як особистість; професійні, щзо характеризують його професійну діяльність; сочіальні, щзо характеризують комунікативні якості викладача, взаємодію з учасниками освітнього проиесу.

Висновки: Ефективність $і$ оптимізаџія процесу навчання українських та іноземних студентів залежить як від педагогічного професіоналізму, так $i$ від індивідуально-психологічних $i$ характерологічних особливостей особистості викладача.

Ключові слова: професійна компетенція викладача, українські та іноземні студенти, університети технічного профілю, компетентнісний підхід, професіографічний моніторинг.

\section{Cite this article as:}

Bielikova, O. V., Dytiuk, S. O., \& Krech, T. V. (2019). Special Moments in Ukrainian and Foreign Students Perception of a Lecturer's Personality. International Journal of Education and Science, 2(1), 14-21. doi:10.26697/ijes.2019.1.02

The electronic version of this article is the complete one and can be found online at: http://ijes.culturehealth.org/index.php/en/archive

This is an Open Access article distributed under the terms of the Creative Commons Attribution License, which permits unrestricted use, distribution, and reproduction in any medium, provided the original work is properly cited (http://creativecommons.org/licenses/by/4.0/deed.en). 